\title{
Youth Employment in Start-up Ventures in Jordan: An Exploratory Study
}

\author{
Andrea Caputo* \\ Lincoln Business School \\ University of Lincoln \\ Lincoln, Lincolnshire LN6 7TS, UK \\ *Corresponding author \\ Rosa Lombardi \\ Department of Research \\ Link Campus University of Rome \\ Rome, 00133, Italy \\ Farah Akeel, Haneen Almallah, Basma Dakkak and Nadia Quabbaj \\ Department of Business Administration \\ King Talal Faculty of Business and Technology \\ Princess Sumaya University for Technology \\ Amman, 11941, Jordan
}

\begin{abstract}
Youth in developing countries are faced with high unemployment rates, even when they possess higher education degrees. In the developing world, small business and entrepreneurial ventures constitute the main drivers of economic development and offer employment opportunities for youth. Nevertheless, when faced with a career decision after their studies, youth seem to prefer careers in established companies over start-ups. As a consequence, start-ups find it more difficult to find and hire the right employees although they are available in the market. This study aims at examining the factors behind youth career decisions to work for a start-up company and provides suggestions for both research and practice. By relying on both entrepreneurship and career decision-making literature, we developed a theoretical model that includes background factors and individual characteristics. Results from a survey on youth graduates from Jordan show that a high school education fostered critical thinking and international exposure, the participation in entrepreneurial events and creativity, which predicted the willingness to work for a start-up.
\end{abstract}

Keywords: Youth, start-up, career decision-making, entrepreneurship, education, unemployment, developing countries, Jordan.

This version is the paper is the Author accepted version post-review. Citation to this paper should be done as follow until the publication becomes available:

Caputo A., Lombardi R., Akeel F., Almallah H., Dakkak B., Qubbaj N. (2015), "Youth Employment in Start Up Ventures in Jordan: An Exploratory Study", International Journal of Entrepreneurship and Small Business, in-press. 


\section{Biographical notes}

Andrea Caputo is Lecturer in Strategic Management at the Lincoln Business School of the University of Lincoln in the United Kingdom. He has formerly served as Assistant Professor of Business Administration at Princess Sumaya University for Technology, in Jordan from 2013 to 2015. Dr Caputo received his PhD in Management in 2013 from the University of Rome 'Tor Vergata', School of Economics, in Italy. He has also been, in 2015, Visiting Faculty Member at the University of Queensland Business School, and, in 2012, Visiting Scholar at The George Washington School of Business, in Washington DC, USA. Since 2014, he has been serving as Regional Representative for Italy \& South Europe at the International Association for Conflict Management. Dr Caputo's main research expertise is related to negotiation, decision-making, entrepreneurship and strategic management; covering subjects such as integrative negotiations, strategic negotiations, cultural differences, and entrepreneurship in developing countries. He has authored a number of international publications and his work has been presented at international conferences, such as the International Association for Conflict Management, the Academy of Management, and the European Academy of Management. In 2014, the International Journal of Conflict Management has awarded his work as Emerald Highly Commended Paper of the year. He is also an active management consultant and negotiator.

Rosa Lombardi is Assistant Professor of Business Administration at Link Campus University in Rome (Italy). She is eligible as Associate Professor of Business Administration under Italian National Qualification. She had her Ph.D. in Business Administration. She serves in the Editorial Board and Guest Editor of many international peer reviewed academic journals. Her main research interests cover the following topics: corporate governance, corporate disclosure, intellectual capital, decision-making, evaluation firm and business network. She has more than 60 publications (books, articles, proceedings, etc.). She is Chair of the Research Committee on "Intellectual Capital" and Associate EMAB Fellow at the EuroMed Research Business Institute. She is Editorial Board Member in Business System Laboratory.

Farah Akeel, Haneen Almallah, Basma Dakkak, and Nadia Quabbaj are graduate students in Business Administration from the Department of Business Administration at the King Talal Business School of Princess Sumaya University for Technology in Amman, Jordan.

Acknowledgements: The authors would like to thank the Editor and the three anonymous reviewers for their valuable comments. A special thanks goes also to all the participants of this study. This paper is the joint work of the six Authors, in particular Farah Akeel, Haneen Almallah, Basma Dakkak and Nadia Quabbaj collected while working on their graduation project, paragraphs 1, 2, 3, and 5 are by Andrea Caputo; while paragraph 4 is by Rosa Lombardi; paragraph 6 is by all authors. 


\section{Youth Employment in Start-up Ventures in Jordan: An Exploratory Study}

\section{Introduction}

Students all over the world are faced with the decision of choosing a career and the job they want to carry on with after their university journey is over. Some enter this journey with a goal in mind, while others go wherever life takes them. When it comes to making these decisions, young people are given the choice between selfemployment, employment and unemployment (Knight, 2012).

The aim of this paper is to contribute to the Special Issue on "Youth Involvement in Entrepreneurship in the Developing World" of the International Journal of Entrepreneurship and Small Business, by investigating the reasons behind youth decisions to work for a Start-up. To ensure context relevancy, we chose to analyse the Jordanian context as representative of the developing countries in the Middle East. Indeed, Jordan shares cultural and religious values and norms with the other Middle Eastern countries associated with a more stable government that is currently supporting entrepreneurship. These characteristics make Jordan a prolific context for analysis and research in the field of entrepreneurship and youth involvement in the workforce (Dakkak, 2011; Dana, 2000; Hattab, 2010; Hussainat, Ghnimat, \& Rabee Al-dlaeen, 2012).

Career decisions, as all decision-making processes, are affected by a series of internal and external factors, such as personality, culture, past experiences, role models and circumstances. In Jordan, a context with a strong culture (Hofstede, 1994), youth decisions are most affected by family duties, expectations, and obligations towards others, compared to individuals living in a context where cultural traditions are less prominent (Hall \& Hall, 1990; Hall, 1985, 1989). Thus, for Jordanian youth, the decision-making process is strongly influenced by: (1) expectations of family members, (2) ideas promoted by friends and peers, and (3) what is normally accepted or unaccepted by society. In addition to culture, career decisions are particularly affected by the person's level of internal self-realization, personality, past experiences, role models, and external opportunities presented by the current environment (Domadenik \& Pastore, 2006; Flouri \& Buchanan, 2002; O'higgins, 1997; Scarpetta, Sonnet, \& Manfredi, 2010; Van Auken, Fry, \& Stephens, 2006). 
Globalisation, technology, unstable market conditions, population density, the emergence of specialisation, and high unemployment rates have all created a shift toward the creation of small sized companies, popularizing entrepreneurship (Carree \& Thurik, 2010; Todorovic \& McNaughton, 2007). Through job creation opportunities by start-up companies, entrepreneurial activity has positively impacted unemployment rates, particularly for the younger population (Ayyagari, DemirgüçKunt, \& Maksimovic, 2011; Devins, 2009; Maritz, 2004). This trend has been recognised by the growing importance of entrepreneurial education and the encouragement of entrepreneurial behaviours in universities' curricula and companies' training programmes (Domadenik \& Pastore, 2006; Mohamad, Lim, Yusof, Kassim, \& Abdullah, 2014; Peterman \& Kennedy, 2003; Rodrigues, Raposo, Ferreira, \& Do Paco, 2010).

We chose Jordan as the context for our analysis for the following reasons: (1) the importance of entrepreneurship and small businesses for its economy (GEM, 2009, 2014; The World Bank, 2015; U.S. Department of Commerce, 2014); (2) the country's characteristic political stability and security; and (3) the similarity of its cultural and societal context with the Middle East region. Moreover, due to the economic recession, unemployment rates have steadily increased in Jordan, particularly among the larger portion of the population, the youth (Hussainat et al., 2012; The World Bank, 2015). In this context, many head towards self-employment, fostering the "push effect" of entrepreneurship, meaning, people are driven by the need for security and necessity to open a start-up business (Amit \& Muller, 1995; Brünjes \& Diez, 2013; Dawson \& Henley, 2012; Ritsilä \& Tervo, 2002). As a consequence, these entrepreneurs contribute positively to the economy through the pull effect of entrepreneurship, and become a primary source of employment opportunities for youth (Amit \& Muller, 1995; Carree \& Thurik, 2010).

An important element for the success and survival of start-ups is the availability of human capital (Carter, Brush, Greene, Gatewood, \& Hart, 2003; Gopinath \& Upadhyay, 2002; Hill, Malikowski, Volini, Walsh, \& Press, 2014; Lasch, 2011). Indeed, start-ups and small businesses are faced with the challenge of finding the right employees (Carree \& Thurik, 2010; Lasch, 2011; Piore \& Sabel, 1984). In a study on entrepreneurs in Turkey, Benzing, Chu, and Kara (2009) state that start-ups face important problems in attracting and retaining reliable employees. The Forum of Young Global Leaders, which aims to accelerate entrepreneurship in the Arab World, 
highlighted that the issue of finding the right employees is faced by a large number of start-up companies (Saddi \& Soueid, 2011). Therefore, we claim that there is a need for academic research to address this issue and further analyse the relationship between start-ups and youth employment in developing countries, which is the aim of our research.

Due to our professional and academic experience, we argue that when presented with a choice, Jordanian skilled youths resist working for start-ups and generally prefer bigger, established companies. As such, this hypothesised trend gives rises to the questions: Are youth considering working for start-up companies? If so, what role does education play in affecting this decision? Which individual characteristics play a role in the decision-making process? Indeed, education has been proven to be a major influence on a person's decision to work or not work for a start-up company (Benzing et al., 2009; Dioneo-Adetayo, 2006; Mohamad et al., 2014; Owualah, 1999). Economic and entrepreneurial education helps students value, understand and contribute to the development of the economy and stimulates their value creation and innovative spirit (Borozan \& Dabić, 2008; Dabic, Daim, Bayraktaroglu, Novak, \& Basic, 2012; Henderson \& Robertson, 2000).

This study aims to answer the above research questions and discover the specific factors that influence the decision of students and fresh graduates from Jordanian universities to work or not work for start-up companies. We interviewed several entrepreneurs and then developed a survey, which was administered to 127 Jordanian youths. This research can be beneficial for scholars, practitioners, entrepreneurs and Jordanian youth interested in understanding the topic. Moreover, realization of the factors luring Jordanian youth to work for start-up companies may lead to an emphasis among universities and employers to cultivate entrepreneurship in Jordan in the future.

In the next section we present a review of the existing literature on youth entrepreneurship and career decision processes. We then present the methods deployed in our research. Results are subsequently presented and discussed to draw conclusions and directions for future research. 


\section{Literature review and theoretical background}

\subsection{Unemployment and youth career decision-making}

The rate of youth unemployment in the world, and particularly in the developing world, is alarming and an issue with a long past (Owualah, 1999). However, few data can clarify this claim. According to the OECD, average youth employment rates in OECD countries are consistently 1.5 to 4.5 times higher than adult unemployment rates (Vogel, 2013). Jordan's population is 6.1 million, with a male/female ratio of 102:100. More than $70 \%$ of its population is under 30 years of age, and those between the ages of 15 and 24 comprise $22 \%$ of the entire population, of which $48 \%$ are women. In Jordan, youth unemployment, which refers to the share of the labour force aged 15-24 without work but available for and seeking employment, rose from 30.1\% in 2010 to $33.6 \%$ in 2013, according to World Bank data; while the average unemployed rate is around $12 \%$. Youth are facing high unemployment rates, making up nearly $61 \%$ of the total number of people that are unemployed, which is estimated at 105,000 unemployed youth. This has happened despite an annual GDP growth rate between $2.5 \%$ and $3 \%$, forecasted to reach $4 \%$ by 2017 . As for other developing countries, this rise has been partially attributed to population explosion.

The highest percentage of unemployment resides outside of Amman, the capital of Jordan. The largest employers are the Government, the Military and the Mega National Project, which have reached their ultimate capacity. Due to the conditions, many capable and intelligent youth are leaving Jordan to look for job opportunities abroad (Deli, 2011).

In a recent study aimed at exploring the determinants of labour market participation of young people in Poland and Slovenia, it was found that age, gender, training and education, civil status, and nationality are major influencers on the unemployment rate and the participation of individuals in the labour market (Domadenik \& Pastore, 2006).

In these conditions, the creation of job opportunities is a fundamental factor. Historically, small businesses are the ones creating most jobs (Ayyagari et al., 2011; Devins, 2009; Maritz, 2004). Two-thirds of new jobs were created by companies with twenty employees and four out of five new jobs were created by businesses with 100 employees or lower. A study examining entrepreneurial mobility in the Middle East and North Africa (MENA) region found that start-ups attract creative, smart and innovative people that are determined to achieve success, which increases economic 
activity, creates jobs and unlocks new opportunities for others (Nasr \& Rostom, 2013). Previous research has shown that unemployment can have several effects on individuals, particularly when they are still at a young age and in a stage of professional self-development (Blakely, Collings, \& Atkinson, 2003; Vogel, 2013; Winefield, 1997).

The relationship between entrepreneurial activity and unemployment is surrounded by ambiguity. The positive relationship between the two is exhibited in the "Theory of Economic Development" which explains how entrepreneurship causes the development of the economy. Firms act in a creative, innovative way by introducing new technologies that make current ones obsolete, a term referred to as creative destruction (Schumpeter, 1934). Studies have supported this positive relationship, explaining how start-up companies provide job opportunities and help decrease unemployment rates (Ayyagari et al., 2011; Devins, 2009; Maritz, 2004; Thurik \& Wennekers, 2004; Vogel, 2013). In addition, entrepreneurial activity is seen as an economic development in indigenous societies, where poverty, shifting economic forces, low education and poor health care is common (Dana \& Dana, 2008; Dana, 1995; Ramadani, Gërguri, Dana, \& Tašaminova, 2013). These indigenous populations are taking on entrepreneurial activities to support their economies (Peredo, Anderson, Galbraith, \& Honig, 2004).

We aim to contribute to the development of knowledge through our research in understanding how the decision to work for a start-up is taken by a fresh graduate.

According to Hodkinson and Sparkes (1997), previous theories of career decision, among their differences, focus on three main dimensions: i) decision-making is fundamentally an individual process; ii) it contains large elements of technical rationality; and iii) the primary factors determining the choice remain in the sphere of influence of the individual. In their paper, the authors acknowledge how their alternative theory of career decision-making blends social and cultural factors with personal choices, considers a sophisticated model of learning and merges individual preferences with opportunities. Other than this theory, three main theories have emerged in the literature: the trait theory (Kidd, 1984; Law, 1981), the developmental model (Ginzberg, Ginsburg, Axelrad, \& Herma, 1951; Super, 1953), and the social learning theory (Krumboltz, 1979). The first one, the trait theory, refers to the matching of the person with the placement, by identifying traits of personality, skills and interests that are needed in certain jobs (Kidd, 1984; Law, 1981). The second, the 
developmental model, argues that there are developmental stages of career decisionmaking, therefore good career choices need maturity and experience (Ginzberg et al., 1951; Super, 1953). The third one, the social learning theory, addresses the interaction between social and cultural factors on decision-making (Krumboltz, 1979). By relying on these theories, we argue that certain backgrounds, such as education, and certain individual characteristics will influence the decision to join a start-up or not. To identify these characteristics, we will discuss, in the next sub-sections, first the studies on youth involvement in start-ups and entrepreneurship; then, we will address the specific individual characteristics that might predict youth decisions to join an entrepreneurial venture as a career choice.

\subsection{Youth involvement in start-ups}

It is clear from previous research that the push effect of entrepreneurship is often correlated with unemployment. People are driven by the need for security and necessity to open a start-up business (Amit \& Muller, 1995; Brünjes \& Diez, 2013; Dawson \& Henley, 2012; Ritsilä \& Tervo, 2002). In developing countries, businesses created as a result of the push effect have tended to originate from the need for survival of the unemployed, who chose to be self-employed (Owualah, 1999). For this and other reasons, most of the research about youth and entrepreneurship focus on this dichotomy and the decision to become an entrepreneur. Less has been done with regards to why a youth would choose to work for a newly born business.

The stream of research focusing on graduates (Lüthje \& Franke, 2002; Peterman \& Kennedy, 2003; Smart, 1986) and youth in entrepreneurship (Poschke, 2013; Rees \& Shah, 1986; P. D. Reynolds, 1991; P. Reynolds, Storey, \& Westhead, 1994) has developed in the last decades and has mainly focused on recognizing patterns according to individual characteristics such as age, gender, race and family background (Campanella, Della Peruta, \& Del Giudice, 2013). A number of additional factors has been studied by a limited number of studies, such as social norms and university culture (Åstebro, Braunerhjelm, \& Broström, 2013; Braunerhjelm, 2007) or the type of university attended (Brewer, Eide, \& Ehrenberg, 1999).

A growing number of studies have investigated the issue of opportunity recognition (Singh, 2001). Indeed, a significant barrier to youth and graduate entrepreneurship 
comes from the fact that young people do not always recognise valid opportunities (Campanella et al., 2013). However, previous research has addressed how this issue can be avoided thanks to the informal networks of the nascent entrepreneur (Arenius \& De Clercq, 2005; Korsgaard, 2011; Nijkamp, 2003; Shane \& Cable, 2002), such as family, friends and other sources of tacit knowledge (Campanella et al., 2013). For example, Le (1999) pointed out that if a graduate has a father with entrepreneurial experience, he will be more likely to take the path of self-employment. Others have highlighted the influence of family background (Birdthistle, 2008; Tackey, 1999; Zellweger, Sieger, \& Halter, 2011) or family role models (Hout \& Rosen, 1999).

The construct of role models calls for further clarification. The decision-making process of youths is affected by the role models they experience in their life (Flouri \& Buchanan, 2002; Hodkinson \& Sparkes, 1997; Krumboltz, 1979). This is particularly true for teenagers, who are influenced by a variety of adults and peers. Role models can be instrumental in developing career aspirations, educational objectives, behaviours and attitudes. A substantial body of literature has shown that individuals learn through modelling others. As we gather experiences during our life, we define what is socially acceptable and what is not. Of course, these models come from different environments, the family, close friends, school and society at large.

The role of the family as a fundamental influence on youth career development has been widely addressed. Even though parents and siblings do not necessarily attempt to influence occupation choices, they are the main role models for youth (Flouri \& Buchanan, 2002; Zellweger et al., 2011). It has been validated that role models provide examples of entrepreneurship, and discussion about it fosters interest in starting a business (Van Auken et al., 2006).

In order for start-up companies to succeed and contribute positively to the growth of the economy, the right employees should occupy opportunities that are created. One way to enhance an entrepreneurial culture is through motivating individuals to work for start-ups because without creative employees, a start-up company won't succeed (Gibrat, 1931).

As previously said, research studies have shown that entrepreneurial activity has a positive impact on unemployment and economic development rates (Ayyagari et al., 2011; Devins, 2009; Maritz, 2004), whether this activity is driven by a push effect or a pull one. However, these studies have implied that the development of start-up companies, and their contribution to the economy under these tough, turbulent 
circumstances, is only a short term one unless job positions are occupied by individuals who dedicate themselves to these small start-up companies and contribute to its growth and development (Benzing et al., 2009).

Individuals can match the need of start-up companies by going through stages of exploration of one's self and the environment with a degree of decidedness and commitment to one's own decision (Germeijs \& Verschueren, 2006). Most, if not all, of the research conducted on entrepreneurship addresses the issue and factors that prevent individuals from starting their own business, and assess the individual's ability to make a sustainable career option in starting his/her own business (Izquierdo \& Buelens, 2011). Very few studies have been made to assess the factors influencing a person's decision to work or not work for an already formed start-up company. In particular, this has not been addressed yet by taking into consideration a developing country's industry structure, unemployment causes, and cultural and demographic patterns affecting a person's decision, as well as the education system. The purpose of this study is to draw a connection between the characteristics of start-up employees and the characteristics of Jordanian University graduates in relation to their economic status, culture, family and education, to assess the reasons behind the reluctance of graduates to work for a start-up company. The next sections will discuss and develop a theoretical model based on the hypotheses. We start with discussing the role of education and individual characteristics. Since there is a lack of clear literature on motivations to work for a start-up, we borrow our theoretical discussion from the more established field of entrepreneurship.

\subsection{Entrepreneurial education and the decision to work for a start-up}

There has been an unprecedented expansion in the number of youths and graduates from secondary and higher education institutions, as part of policies in Jordan as well other developing countries, to stimulate and support youth education. As a consequence, the role of education in tackling the issue of our interest is particularly important. The question, "Can entrepreneurship be taught?" has been a debate that has taken the attention of many universities and organisations. The "trait approach" specifies that entrepreneurship is a personal trait that cannot be taught, but rather is inherited (e.g. Herron \& Sapienza, 1992; Olson, 1987). Others state that it is a skill 
like any other that can be acquired and learned (Klofsten, 2000; Vesper \& Gartner, 1997).

Many studies have been conducted to clarify the relationship between entrepreneurial activity and education and have shown that there is a clear connection (Galloway \& Brown, 2002; Gorman, Hanlon, \& King, 1997; Kolvereid \& Moen, 1997).

In one study, the results showed that one of the most influential factors in choosing entrepreneurship as a career is education (Mohamad et al., 2014). Henderson and Robertson (2000) came up with similar results, implying that education on entrepreneurship can lead students to an entrepreneurial career. Kolvereid and Moen (1997) emphasised that graduates who have undertaken entrepreneurial courses show stronger entrepreneurial intentions compared to those who did not.

In an effort to evaluate education and teaching implications on students' attitudes toward having a future entrepreneurial job, it is stated that knowledge acquired through teaching affects a person's decision about their future job in relation to the extent these students believe in the impact of knowledge on their future. Therefore, it is implied that teachers and students should both be responsible for creating a learning environment that promotes creativity and risk-taking, as well as fostering an entrepreneurial culture (Borozan \& Dabić, 2008).

In the United States, the importance of entrepreneurial education has been widely acknowledged. Entrepreneurship has been a part of the curricula of higher education in North America for over 50 years. In fact, the first graduate course in entrepreneurship was offered at Harvard University in 1948. In Europe, entrepreneurial education is integrated in primary and secondary education in different ways: it is integrated into existing subjects (cross-curricula approach), or it is a separate optional or compulsory subject. In the MENA Region, only 37 regional universities - fewer than 10 per cent of the universities in the MENA region - offer entrepreneurial courses. Just 17 universities in the region have centres for entrepreneurship and a mere five actually offer a major in entrepreneurship (Saddi \& Soueid, 2011).

The high school education system in Jordan, although mainly concentrated on high stake exams, the so-called Tawjihi, includes international standards also, such as the International Baccalaureate (IB), the International General Certificate of Secondary Education (IGCSE), and the Scholastic Aptitude Test (SAT). The government sets the curriculum so that the main determinant of what major or what university a youth gets 
into is based on their grade for these high stake exams. In the words of a junior at the Jubilee School in Amman, "It [the Tawjihi] will determine what I study, where I study, whom I marry, and who I socialise with, it will determine everything about my life". These systems promote memorisation over critical thinking and analysis. In fact, critical thinking questions on the Tawjihi in Jordan are limited to 20\% (Dakkak, 2011). In schools, it is found that students are not educated about entrepreneurship and no start-up culture is cultivated. One study has suggested that the ministries of education in Jordan should join forces with the Arab League Educational, Cultural and Scientific Organization (ALECSO) to create a regional combined effort to push for a curriculum that includes entrepreneurship (Saddi \& Soueid, 2011).

It comes as a consequence that education affects youth decision processes. In order to make a sustainable career decision, individuals should go through a number of different stages that mainly consists of: awareness, self exploration, environment exploration, in-depth exploration, decision making, and commitment (Dakkak, 2011). This process is determined by the degree of active engagement in identity construction and exploration of various alternatives, and the commitment to a specific set of alternatives (Marcia, 1980). The higher the level of exploration and decidedness, the more viable and sustainable the career option and goal is. According to what we have discussed so far, we hypothesise the following:

Hypothesis 1a: Students who have undertaken entrepreneurial courses and events are more likely to be willing to work for a start-up company.

Hypothesis 1b: Students who have undertaken an international high school education are more likely to be willing to work for a start-up company.

\subsection{Individual characteristics and the decision to work for a start-up}

Personal characteristics and individual differences affect general decision-making processes (Aminoff et al., 2012; Bazerman \& Moore, 2013; Spicer \& Sadler-Smith, 2005). As previously said, career decision-making processes are not only affected by one's educational background but also by role models (Flouri \& Buchanan, 2002; Van Auken et al., 2006), self efficacy (Bandura, 1977; Bullock-Yowell, Andrews, \& Buzzetta, 2011; Luzzo, 1993), and individual characteristics (Kidd, 1984; Law, 1981). 
We already claimed that there is a lack of research on career decisions to join a startup or a recently born small business when looking at employment opportunities. Despite the lack of academic research, there is a vast amount of practice-oriented publications that offer advice on the decision to work for a start-up. Websites such as entrepreneurs.com and inc.com, as well as newspaper and magazines, such as The Guardian or Forbes, offer a vast source of reliable, though not scientific, knowledge. Therefore, to build up on our argument, we mixed insights from research and practice. Existing theories on youth career decision-making identify these processes and that, other than educational background and experience (Hodkinson \& Sparkes, 1997; Krumboltz, 1979), individual characteristics should be relevant for the matching of the individual to a placement (Kidd, 1984; Law, 1981). Accordingly, a first step for those individuals to match the need of start-up companies is tied to the degree of decidedness and commitment to one's own decision (Germeijs \& Verschueren, 2006). Indeed, working in a start-up company is challenging and requires a strong commitment. In many cases, the prospective employee would have the majority of the income in the form of a variable salary subject to performance. Therefore, we argue that:

Hypothesis 2: There is a positive relationship between the level of decidedness on a career option and the willingness to work for a start-up company.

Working for a start-up might be also perceived as a more risky option. Many companies face failure in the early stages of their lives (Abatecola, Cafferata, \& Poggesi, 2012; Ciavarella, Buchholtz, Riordan, Gatewood, \& Stokes, 2004; Zimmerman \& Zeitz, 2002). When faced with the alternative to work for an established company or for a recently born small business, it is reasonable for prospective employees to take into consideration job security. Therefore we argue the following:

Hypothesis 3: Individuals characterised as risk takers show more willingness to work for a start-up company.

Another factor to take into consideration when facing the decision to work for a startup is the level of changes associated with that decision. Indeed, working for a start-up might mean facing many changes in a short amount of time that characterise the early 
life of any small organisation, such as job rotation and organisational changes. Therefore we postulate:

Hypothesis 4: Students who are more curious and willing to explore new experiences are more likely to be willing to work for a start-up company.

Finally, matching between the right employee and start-up will require employees to have creativity. Indeed, creativity is among the main sources of innovation (BassettJones, 2005), and innovation is pivotal for entrepreneurial success (Leiblein, 2007). Therefore, we postulate:

Hypothesis 5: Creative individuals are more likely to be willing to work for a start-up company.

Having provided a theoretical context for our analysis by borrowing theoretical constructs from the established literature on entrepreneurship, in the next section we present the method deployed for our research, then we will present and discuss the results.

\section{Method}

\subsection{Participants and design}

A total of 127 Jordanian youths, aged from 20 to 26, voluntarilyy participated in the study. Of these participants, 28.3 per cent were males $(\mathrm{N}=36)$ and 71.7 per cent were females $(\mathrm{N}=91)$; 74.6 percent hold a Tawjihi certificate and 35.4 per cent hold other types of certificates (International Baccalaureate; International General Certificate of Secondary Education; Scholastic Aptitude Test).

The design of the study included observed demographic variables (such as gender, age, level of education), type of high school diploma, risk propensity, decidedness, creativity, curiosity, and personality. 


\begin{tabular}{lcc}
\hline \hline & $\mathrm{N}$ & $(\%)$ \\
\hline Gender & & \\
Male & 36 & 28,3 \\
Female & 91 & 71,7 \\
Level of Education & & \\
High School & 8 & 6,3 \\
College & 16 & 12,6 \\
Bachelor's Degree & 100 & 78,7 \\
Master's Degree & 3 & 2,4 \\
Type of High School Diploma & & \\
SAT & 9 & 7,1 \\
IB & 14 & 11,0 \\
IGCSE & 22 & 17,3 \\
Tawjihi & 82 & 64,6 \\
Employment Status & & 65,4 \\
Unemployed & 83 & 34,6 \\
Employed & 44 & 61,4 \\
Attended Entrepreneurship Courses & & 28,3 \\
No & 78 & 10,2 \\
Yes, one course & 36 & 21,3 \\
Yes, more than one course & 13 & 32,3 \\
Attended Entrepreneurship Events & 27 & 46,5 \\
No & 41 & 59 \\
Yes, once & & \\
Yes, more than once & & \\
\hline
\end{tabular}

\subsection{Procedure and materials}

All participants were informed of the nature of the study. After consenting to take part in the study, in a totally anonymous way, participants were presented with demographic questions and self reported inventories to measure the aforementioned variables. The questionnaires were distributed both in the English and Arabic languages in order to ensure full understanding by participants. No differences in answers were reported between the two languages. Participants were also asked questions regarding entrepreneurial education, such as if they ever had received a structured course, participated in an event or received spot classes on the topic. Moreover, participants were asked questions to understand their perception of the likelihood of getting a job in Jordan, for example, "To what extent do you think this job opportunity will match your wants and expectations?" or "To what extent do you believe that in order to find a job, you need to move out of Jordan?"

After these questions, participants were asked to complete self-reported inventory on risk propensity, decidedness, creativity, curiosity and personality. Then, they were 
presented with an original scenario where they had to choose between working for a start-up and an established company.

\subsubsection{Risk propensity}

To assess risk-propensity Rohrmann's Risk Orientation Questionnaire (RQQ; Rohrmann, 2002, 2005) was employed. Participants self reported their agreement with 12 statements expressing risk aversion or risk-propensity on a 5-point Likert scale that ranged from 1 (strongly disagree) to 5 (strongly agree). Reported scores were then averaged for each scale. The Rohrmann's scale has been widely used and validated in the literature for various purposes (Meertens \& Lion, 2008), such as young drivers' behaviour (Hatfield \& Fernandes, 2009), gender differences (Ronay \& Kim, 2006), natural hazards (Bird, 2009), and employee behaviour (Roszkowski \& Grable, 2009). In terms of reliability, Cronbach's alpha was used and scored 0.721 for risk pro pension and 0.682 for risk aversion.

\subsubsection{Decidedness}

To assess decidedness, the Career Decidedness Scale (John W Lounsbury, Tatum, Chambers, Owens, \& Gibson, 1999) was employed. The scale is made of six statements to which the respondent self reported their level of agreement on a 5-point Likert scale that ranged from 1 (strongly disagree) to 5 (strongly agree). This scale has received constructive validation in recent times (J W Lounsbury \& Gibson, 2002; John W Lounsbury, Hutchens, \& Loveland, 2005) and has been widely used in employment studies (Earl \& Bright, 2007; Feldt \& Woelfel, 2009; Uthayakumar, Schimmack, Hartung, \& Rogers, 2010). In terms of reliability, Cronbach's alpha was used and scored 0.751 .

\subsubsection{Creativity}

To assess creativity, the Creative Personality Scale (CPS; Kaufman \& Baer, 2004) was employed. This scale, based on a 5-point Likert scale, was built with items measuring creativity, from the Hogan Personality Inventory (Hogan, Hogan, \& Roberts, 1996; HPI; Hogan, 1992), and with items measuring imagination, from the Cattell's Personality Factors Questionnaire (16PF; Russell \& Karol, 1994). The CPS has been widely validated and used in many fields of research, such as psychology, education, problem solving and management (Kaufman, Cole, \& Baer, 2009; Kaufman, 2006; Silvia et al., 2008; Silvia, Wigert, Reiter-Palmon, \& Kaufman, 2012). In terms of reliability, Cronbach's alpha was used and scored 0.631 .

\subsubsection{Curiosity}


To assess curiosity, the Curiosity and Exploration Inventory (CEI; Kashdan, Rose, \& Fincham, 2004) was employed. This inventory is comprised of two dimensions: exploration (appetitive endeavour for novelty and challenges) and absorption (full engagement in specific activities). It is a seven-item inventory that measures respondents' recognition, pursuit, and integration of new and challenging stimuli and experiences. Respondents answer each item using a five-point Likert-type scale ranging from 1 (strongly disagree) to 5 (strongly agree). The CEI has been widely validated and used in the field of psychology (Leonard \& Harvey, 2007; Neff, Rude, \& Kirkpatrick, 2007; Porfeli \& Skorikov, 2010). In terms of reliability, Cronbach's alpha was used and scored 0.67.

\subsubsection{Scenario}

The last part of the questionnaire constituted a scenario. The scenario was originally written after interviewing three start-up companies in Jordan: Shabab Jobs, Impact MENA, and Beladcom. The scenario was built to assess the opportunities, type of work environment, benefits and drawbacks of working for a start-up company as opposed to the opportunities, type of work environment, benefits and drawbacks of working for a well-established company. Participants were asked to imagine that they had applied and received the same offer from both companies, and were asked to rate to what extent they would be willing to work for each company. Participants were also asked to provide their answers and those have been analysed by the researchers.

\section{Results}

In this section, the results of the multiple linear regression model employed and the qualitative analysis of participants' motivation for accepting or rejecting to work for a start-up are presented. The willingness of participants to work for a start-up company served as a dependent variable, and 11 independent and control variables were employed (Table 2). In operating the multiple linear regression model, a bootstrapping procedure using the bias corrected accelerated (BCa) method with 2000 bootstrap samples were deployed to ensure robustness. Results from collinearity statistics showed VIF values that were acceptable and higher than 1, for all the variables included in the model.

Attendance at entrepreneurial courses, which served to measure formal entrepreneurial education, showed no effect on the dependent variable, as opposed to entrepreneurial events $(p=.05)$, which showed a positive effect. 
The level of decidedness, GPA, employment status, gender, curiosity, and risk propensity showed no statistically significant effect on willingness to work for a startup company.

Results showed that creativity had a significant, strong positive effect on the dependent variable $(p=.02)$ and the same can be said for age $(p=.013)$. In terms of high school education, as argued in the background theory section, youth who received an international high school education, rather than partaking in the Jordanian Tawjihi system, showed a positive relationship with willingness to work for a start-up company $(p=.067)$. Meaning, students who hold Tawjihi certificate are more likely to resist working for a start-up company compared to students who hold an IB, IGCSE, or SAT degree.

Table 2 - Multiple Linear Regression Results

\begin{tabular}{lr}
\hline \hline & Willingness to work for a start up \\
\hline Constant) & -1.216 \\
Gender & $(1.306)$ \\
Age & .133 \\
& $(.205)$ \\
GPA & $.076^{*}$ \\
Entrepreneurial Education & $(.040)$ \\
Entrepreneurial Event & -.408 \\
Employment Status & $(.965)$ \\
Risk Propensity & -.090 \\
Decidedness & $(.138)$ \\
Curiosity & $.224^{+}$ \\
Creativity & $(.124)$ \\
Type of High School & .097 \\
Diploma & $(.196)$ \\
& .187 \\
& $(.149)$ \\
& -.038 \\
& $(.125)$ \\
& -.170 \\
& $(.172)$ \\
& $.686^{*}$ \\
& $(.291)$ \\
& $.334^{+}$ \\
& $(.175)$ \\
\hline
\end{tabular}

The results of the qualitative analysis of the motivation of participants from their answers to the scenario can better understanding of the results from the quantitative analyses. Participants who preferred well-established companies had beliefs that they were offered job security, paid salaries, stability and growth in their career. It is interesting and worth noting that these dimensions were not mentioned in the scenario. Therefore, the youth assumed that working for a well-established company 
would have these characteristics. They also perceived that working for a wellestablished company looks good on the resume as it provides them with a better reputation in case of shifting jobs. Moreover, they perceived that constantly changing tasks would kill their career building and drift them away from the main road. Also, promotions and attainment of higher ranks was recognised to be achievable in a wellestablished company more than in a start-up. On the other hand, respondents that preferred working for a start-up company thought that this field would provide them with better business opportunities to explore and experience all fields of the company. Working for a start-up was seen as a valuable means to enhance creativity and gain experiences in various fields through obtaining new skills and knowledge. One of the reasons encouraging participants to work for a start-up was the friendly, more flexible, comfortable, and motivating environment, as well as the chance to work with a team that promotes creative, personal ideas and shows respect for different views. Most respondents thought that working with a team would help them gain more experience, become more involved in the business, and offer more appraisals. It was also stated that their work would be more appreciated and their voices would be heard due to the informal structure of start-ups.

\section{Discussion}

The purpose of this study was to investigate the factors behind youth career decisions to work for a start-up or not. This objective was associated with the intention to find ways to encourage youths to seek a job in a start-up company as a contribution to the economy of a developing country. This section will discuss our results based on the previous literature. The following table summarises all the hypotheses along with the actual results. 
Table 3 - Summary of the Results

\begin{tabular}{ll}
\hline \hline Hypothesis & Actual Results \\
\hline $\begin{array}{l}\text { Hypothesis 1a: Students who have undertaken } \\
\text { entrepreneurial courses and events are more likely to } \\
\text { be willing to work for a start-up company. }\end{array}$ & $\begin{array}{l}\text { Entrepreneurial courses were proven to have no } \\
\text { significant relationship with willingness to work for a } \\
\text { start-up company. However, for those who attended } \\
\text { university, entrepreneurial events did show } \\
\text { significance. }\end{array}$ \\
$\begin{array}{l}\text { Hypothesis 1b: Students who have undertaken an } \\
\text { international high school education are more likely to } \\
\text { be willing to work for a start-up company. }\end{array}$ & $\begin{array}{l}\text { Youth who attended an international high school } \\
\text { showed more willingness to work for a start-up than } \\
\text { students who attended schools following the Jordanian } \\
\text { system. }\end{array}$ \\
$\begin{array}{l}\text { Hypothesis 2: There is a positive relationship between } \\
\text { the level of decidedness on a career option and the } \\
\text { willingness to work for a start-up company. }\end{array}$ & $\begin{array}{l}\text { There was no relationship between a person's level of } \\
\text { decidedness and willingness to work for start-up } \\
\text { companies. }\end{array}$ \\
$\begin{array}{l}\text { Hypothesis 3: Individuals characterised as risk takers } \\
\text { show more willingness to work for a start-up company. }\end{array}$ & $\begin{array}{l}\text { No difference was proven to exist between risk and } \\
\text { non-risk takers in relation to willingness to work for a } \\
\text { start-up company. }\end{array}$ \\
$\begin{array}{l}\text { Hypothesis 4: Students who are more curious and } \\
\text { willing to explore new experiences, are more likely } \\
\text { willing to work for a start-up company. }\end{array}$ & $\begin{array}{l}\text { The study showed no significant relationship between } \\
\text { curiosity and willingness to work for start-ups. }\end{array}$ \\
$\begin{array}{l}\text { Hypothesis 5: Creative individuals are more likely to } \\
\text { be willing to work for a start-up company. }\end{array}$ & $\begin{array}{l}\text { Individuals high in creativity were shown to be more } \\
\text { willing to work for a start-up as opposed to uncreative } \\
\text { ones. }\end{array}$ \\
\hline
\end{tabular}

According to our analyses, the first result showed that individuals who are engaged in entrepreneurial events conducted by their university are more likely to adopt the idea of working for a start-up company, and embrace creativity and innovation. This finding is consistent with previous studies which confirmed the impact of entrepreneurial education on people's willingness to work for start-up companies (Henderson and Robertson, 2000). In a study aiming to estimate the factors influencing the career decisions of Malaysian graduates to take entrepreneurship as a career option, results have shown that education, family and economic factors are the most influential factors. It is suggested that more entrepreneurial education should be included in the curriculum. Also, individuals who come from families that are supportive and engaged in entrepreneurial activity are more motivated to take entrepreneurship as a career option (Mohamad et al., 2014).

In terms of secondary education, Tawjihi education, based on memorisation rather than critical thinking, proved to have a negative effect as predicted and in accordance with the literature (Dakkak, 2011). Indeed, the education system in Jordan does not provide a well-rounded exploration of opportunities, and has a lack of a critical, innovative, risk taking approach to teaching (Dakkak, 2011) that takes into 
consideration the personal traits of a person such as self efficacy (Bullock-Yowell et al., 2011) and the family a youth comes from (Hou, Wu, \& Liu, 2013).

Previous research has implied that an individual's level of exploration and decidedness are major determinants of vocational identity (Holland et al., 1980) and sustainable career goals (Germeijs and Verschueren, 2006); in other words, the higher the level of decidedness and exploration, the more sustainable the career goal and the higher a person's confidence in making career decisions. However, this study did not support the literature and had contradicting results, showing no relationship between a person's decision of working for a start-up company and his/her level of decidedness and exploration.

An individual's propensity toward risk is considered to be one of the essential traits needed in order to become an entrepreneur (Knight, 2012) and an employee in an start-up company, due to the risks associated with the early life of a company (Abatecola et al., 2012; Ciavarella et al., 2004; Zimmerman \& Zeitz, 2002). This hypothesis was also supported by several open conversations the authors had with Jordanian entrepreneurs. In contrast, results showed no difference between risk and non-risk takers in relation to the willingness to work for a start-up company.

Hypothesis 4 was not supported, contradicting the few previous studies that related curiosity with the personality factor of openness to experience. Entrepreneurs and entrepreneurial people usually possess the trait of curiosity and this made the authors think that students with this trait would be more willing to like a start-up environment (Ciavarella et al., 2004, Zhao and Seibert, 2006).

The fifth hypothesis was confirmed. Creativity, as an essential personality trait, was proven to have a significant impact on a person's decision to work for a start-up company. This relates to the characteristics of start-up company employees, and is in alignment with what was extracted from the conversations with Jordanian entrepreneurs, which all implied the significance and importance of creativity as a personality trait in the employees of their companies.

In summary, we support the view of a virtuous cycle that has creativity at the centre of it. Youth will need entrepreneurial role models (Flouri \& Buchanan, 2002; Zellweger et al., 2011), both to be willing to consider a career in a start-up, and to develop one of the main traits that is needed to do so, creativity (Bassett - Jones, 2005; Kaufman et al., 2009; Leiblein, 2007). At the same time, creativity, nurtured 
within an entrepreneurial environment, in terms of education and role models (Borozan \& Dabić, 2008; Galloway \& Brown, 2002; Gorman et al., 1997; Kolvereid \& Moen, 1997; Mohamad et al., 2014; Zellweger et al., 2011), will play an important role in the career decision-making process, helping to bridge the gap between the needs of the start-up and the desires and aspirations of youth.

\section{Conclusions and future research directions}

This study aimed to answer the following research questions: Are youth considering working for start-up companies? If so, what role does education play in affecting this decision? Which individual characteristics play a role in the decision-making process? The paper chose Jordan as a case study of analysis representative of developing countries in the region and Middle Eastern culture. To achieve these objectives, we reviewed existing literature on the topic to support our argument. We also applied our personal and professional experience to speculate on the hypotheses that could not be related to previous studies. Indeed, we identified a lack of research on entrepreneurship related to the workforce. Existing literature does not seem to have addressed the questions this study aimed at addressing, such as why youth decide to work for a start-up. We argue that the fit between a start-up and the right employees is fundamental for the start-up's survival, nevertheless there seems to be a resistance of talent in choosing such a career path.

To test our hypotheses, we analysed primary data acquired through a survey distributed to Jordanian university students/graduates. Interviews with Jordanian entrepreneurs helped in clarifying issues that were under researched in the literature. A number of independent variables were extracted from primary data and analysed to test their relationship and correlation with the willingness to work for start-up.

Of these variables, this study has contributed to knowledge in the area by clarifying the significance of creativity, type of high school diploma and participation to entrepreneurial events as the main influencing factors of a student's or a fresh graduate's decision to work for a start-up company or not.

In alignment with the research findings, a couple of recommendations for both practice and policy are suggested in order to fulfil the purpose of this study. First, as previously shown, entrepreneurial activity increases the willingesness of students and fresh graduates to work for a start-up company. Therefore, there should be greater 
emphasis on entrepreneurial courses and activities in schools and universities in developing countries to influence more students to learn about start-ups and entrepreneurship.

Second, Tawjihi students showed low willingness to work for start-ups, which iss explained in theory due to the lack of critical thinking and creativity in this education system. Hence, adjustments should be made to the Jordanian curriculum to add entrepreneurial learning and build critical thinking capacity, in order to support innovative, creative thinking among students to help them make more informed decisions and cultivate Jordan's entrepreneurial sector. Moreover, creativity was highly correlated with the willingness of students to work for a start-up company, which can be supported by entrepreneurial education.

Third, start-ups should focus more on engaging with universities and schools to spread awareness about the importance of entrepreneurship and the opportunities that working for start-ups can bring to a youth's career development. For example, one of the most important aspects of working for a start-up company is that employees gain experience in almost all the departments in the company.

Suggestions for future research can be illustrated through a repeated study with a larger sample size, and more diversification of the sample. A study in the form of a more detailed personality test can also be conducted. Moreover, an in-depth analysis is recommended on the effect of age on the willingness to work, as well as entrepreneurial courses and creativity, which showed great significance in this study. We believe more research should be also carried out on the impact of role models on youth decisions to work for a start-up or not. Indeed, the possible lack of family role models working for a small business or a newly born company might strongly affect youth decisions not to engage in such a career.

\section{References}

Abatecola, G., Cafferata, R., \& Poggesi, S. (2012). Arthur Stinchcombe's "liability of newness": contribution and impact of the construct. Journal of Management History, 18(4), 402-418.

Aminoff, E. M., Clewett, D., Freeman, S., Frithsen, A., Tipper, C., Johnson, A., ... Miller, M. B. (2012). Individual differences in shifting decision criterion: A recognition memory study. Memory \& Cognition, 40(7), 1016-1030.

Amit, R., \& Muller, E. (1995). "Push" and "pull" entrepreneurship. Journal of Small Business \& Entrepreneurship, 12(4), 64-80. 
Arenius, P., \& De Clercq, D. (2005). A network-based approach on opportunity recognition. Small Business Economics, 24(3), 249-265.

Åstebro, T., Braunerhjelm, P., \& Broström, A. (2013). Does academic entrepreneurship pay? Industrial and Corporate Change, 22(1), 281-311.

Ayyagari, M., Demirgüç-Kunt, A., \& Maksimovic, V. (2011). Small vs. young firms across the world: contribution to employment, job creation, and growth. World Bank Policy Research Working Paper, (5631).

Bandura, A. (1977). Self-efficacy: toward a unifying theory of behavioral change. Psychological Review, 84(2), 191.

Bassett Jones, N. (2005). The paradox of diversity management, creativity and innovation. Creativity and Innovation Management, 14(2), 169-175.

Bazerman, M. H., \& Moore, D. (2013). Judgment in Managerial Decision Making (5th ed.). New York, NY: John Wiley \& Sons.

Benzing, C., Chu, H. M., \& Kara, O. (2009). Entrepreneurs in Turkey: A Factor Analysis of Motivations, Success Factors, and Problems. Journal of Small Business Management, 47(1), 58-91. doi:10.1111/j.1540-627X.2008.00262.x

Bird, D. K. (2009). The use of questionnaires for acquiring information on public perception of natural hazards and risk mitigation-a review of current knowledge and practice. Natural Hazards and Earth System Science, 9(4), 1307-1325.

Birdthistle, N. (2008). An examination of tertiary students' desire to found an enterprise. $\begin{array}{llll}\text { Education } \quad \& \quad \text { Training, } & \text { 50(7), }\end{array}$ doi:http://dx.doi.org/10.1108/00400910810909027

Blakely, T. A., Collings, S. C. D., \& Atkinson, J. (2003). Unemployment and suicide. Evidence for a causal association? Journal of Epidemiology and Community Health, 57(8), 594-600.

Borozan, Đ., \& Dabić, M. (2008). Entreprenur's attitudes as a preference of future job vision: an empirical evaluation and implications for teaching. An Enerprise Odyssey: TourismGovernance and Entrepreneurship/Galetić, Lovorka; Čavlek, Nevenka (ur.). Zagreb,: Sveučilišna Tiskara, Do. O., Zagreb, 2008., Str. 329, 342.

Braunerhjelm, P. (2007). Academic entrepreneurship: social norms, university culture and policies. Science and Public Policy, 34(9), 619-631.

Brewer, D. J., Eide, E. R., \& Ehrenberg, R. G. (1999). Does it pay to attend an elite private college? Cross-cohort evidence on the effects of college type on earnings. Journal of Human Resources, 104-123.

Brünjes, J., \& Diez, J. R. (2013). "Recession push"and "prosperity pull”entrepreneurship in a rural developing context. Entrepreneurship \& Regional Development, 25(3-4), 251-271.

Bullock-Yowell, E., Andrews, L., \& Buzzetta, M. E. (2011). Explaining Career DecisionMaking Self-Efficacy: Personality, Cognitions, and Cultural Mistrust. The Career Development Quarterly, 59(5), 400-411. Retrieved from http://proxygw.wrlc.org/login?url=http://search.proquest.com/docview/894273243?acco untid $=11243$

Campanella, F., Della Peruta, M. R., \& Del Giudice, M. (2013). The Role of Sociocultural Background on the Characteristics and the Financing of Youth Entrepreneurship. An Exploratory Study of University Graduates in Italy. Journal of the Knowledge Economy, 4(3), 244-259.

Carree, M. A., \& Thurik, A. R. (2010). The impact of entrepreneurship on economic growth. In Handbook of entrepreneurship research (pp. 557-594). Springer.

Carter, N., Brush, C., Greene, P., Gatewood, E., \& Hart, M. (2003). Women entrepreneurs who break through to equity financing: The influence of human, social and financial capital. Venture Capital. doi:10.1080/1369106032000082586

Ciavarella, M. A., Buchholtz, A. K., Riordan, C. M., Gatewood, R. D., \& Stokes, G. S. (2004). The Big Five and venture survival: Is there a linkage? Journal of Business Venturing, 19(4), 465-483. 
Dabic, M., Daim, T., Bayraktaroglu, E., Novak, I., \& Basic, M. (2012). Exploring gender differences in attitudes of university students towards entrepreneurship: An international survey. International Journal of Gender and Entrepreneurship, 4(3), 316-336.

Dakkak, N. (2011). Obstacles Towards Curriculum Reform In the Middle East: Using Jordan and the UAE as Case Studies. Dubai School of Government Policy Brief, 28(1), 1-7.

Dana, L. P. (1995). Entrepreneurship in a remote sub-Arctic community. Entrepreneurship Theory and Practice, 20, 57-72.

Dana, L.P. (2000). Economies of the Eastern Mediterranean Region: Economic Miracles in the Making. Singapore, London and Hong Kong: World Scientific.

Dana, L. P., \& Dana, T. E. (2008). Ethnicity and entrepreneurship in Morocco: a photoethnographic study. International Journal of Business and Globalisation, 2(3), 209-226.

Dawson, C., \& Henley, A. (2012). "Push" versus "pull" entrepreneurship: an ambiguous distinction? International Journal of Entrepreneurial Behavior \& Research, 18(6), 697719.

Deli, F. (2011). Opportunity and necessity entrepreneurship: local unemployment and the small firm effect. Journal of Management Policy and Practice, 12(4), 38-57.

Devins, D. (2009). Enterprise in deprived areas: what role for start-ups? International Journal of Entrepreneurship and Small Business, 8(4), 486-498.

Dioneo-Adetayo, E. A. (2006). Factors influencing attitude of youth towards entrepreneurship. International Journal of Adolescence and Youth, 13(1-2), 127-145.

Domadenik, P., \& Pastore, F. (2006). Influence of education and training systems on participation of young people in labour market of cee economies: A comparison of Poland and Slovenia. International Journal of Entrepreneurship and Small Business, 3(5), 640-666.

Earl, J. K., \& Bright, J. E. H. (2007). The relationship between career decision status and important work outcomes. Journal of Vocational Behavior, 71(2), 233-246.

Feldt, R. C., \& Woelfel, C. (2009). Five-Factor Personality Domains, Self-Efficacy, CareerOutcome Expectations, and Career Indecision. College Student Journal, 43(2), 429-437.

Flouri, E., \& Buchanan, A. (2002). The role of work related skills and career role models in adolescent career maturity. The Career Development Quarterly, 51(1), 36-43.

Galloway, L., \& Brown, W. (2002). Entrepreneurship education at university: a driver in the creation of high growth firms? Education + Training, 44(8/9), 398-405.

GEM. (2009). Global Entrepreneurship Monitor, GEM-MENA Regional Report 2009 (Middle East \& North Africa).

GEM. (2014). Global Entrepreneurship Monitor, 2014 Global Report.

Germeijs, V., \& Verschueren, K. (2006). High school students' career decision-making process: A longitudinal study of one choice. Journal of Vocational Behavior, 68(2), 189-204.

Gibrat, R. (1931). Les Inégalités économiques. Paris, France.

Ginzberg, E., Ginsburg, S. W., Axelrad, S., \& Herma, J. L. (1951). Occupational choice. New York.

Gopinath, M., \& Upadhyay, M. P. (2002). Human Capital, Technology, and Specialization: A Comparison of Developed and Developing Countries. Journal of Economics, 75(2), 161-179. Retrieved from http://search.ebscohost.com/login.aspx?direct=true \&db=eoah\&AN=2132527\&site=ehos t-live\&scope $=$ site

Gorman, G., Hanlon, D., \& King, W. (1997). Some research perspectives on entrepreneurship education, enterprise education and education for small business management: a tenyear literature review. International Small Business Journal, 15(3), 56-77.

Hall, E. T. (1985). Hidden Differences: Studies in International Communication. Hamburg: Grunder \& Jahr.

Hall, E. T. (1989). Beyond culture. Random House LLC.

Hall, E. T., \& Hall, M. R. (1990). Understanding Cultural Differences: German, French and Americans. Yarmouth, ME: Intercultural Press. 
Hatfield, J., \& Fernandes, R. (2009). The role of risk-propensity in the risky driving of younger drivers. Accident Analysis \& Prevention, 41(1), 25-35.

Hattab, H. W. (2010). The Effect of Environments' Dimensions on the Growth of Female Entrepreneurial Projects in Jordan. Journal of Small Business \& Entrepreneurship, 23(2), 211-223.

Henderson, R., \& Robertson, M. (2000). Who wants to be an entrepreneur? Young adult attitudes to entrepreneurship as a career. Career Development International, 5(6), 279287.

Herron, L., \& Sapienza, H. J. (1992). The Entrepreneur and the Initiation of New Venture Launch Activities. Entrepreneurship: Theory \& Practice, 17(1), 49-55. Retrieved from $\mathrm{http} / / /$ search.ebscohost.com/login.aspx?direct=true $\& \mathrm{db}=\mathrm{bth} \& \mathrm{AN}=9607032860 \&$ site $=\mathrm{eh}$ ost-live

Hill, A., Malikowski, J., Volini, E., Walsh, B., \& Press, D. U. (2014). Global human capital trends 2014. Engaging the 21st-century workforce. Deloitte University Press.

Hodkinson, P., \& Sparkes, A. C. (1997). Careership: a sociological theory of career decision making. British Journal of Sociology of Education, 18(1), 29-44.

Hofstede, G. (1994). Cultures and organisation: Intercultural cooperation and its importance for survival: software of the mind. London, Engliand: Harper Collins.

Hogan, R. (1992). Hogan personality inventory manual. Hogan Assessment Systems Tulsa, OK.

Hogan, R., Hogan, J., \& Roberts, B. W. (1996). Personality measurement and employment decisions: Questions and answers. American Psychologist, 51(5), 469.

Hou, C., Wu, L., \& Liu, Z. (2013). Parental emotional warmth and career decision-making difficulties: A model of intellectual-cultural orientation and conscientiousness. Social Behavior and Personality: An International Journal, 41(8), 1387-1397.

Hout, M., \& Rosen, H. S. (1999). Self-employment, family background, and race. National bureau of economic research.

Hussainat, M. M., Ghnimat, Q. M., \& Rabee Al-dlaeen, M. A. (2012). The Impact of Unemployment on Young People in the Jordanian Community: A Case Study from Unemployed Perspective. Asian Social Science, 9(1), p155.

Izquierdo, E., \& Buelens, M. (2011). Competing models of entrepreneurial intentions: the influence of entrepreneurial self-efficacy and attitudes. International Journal of Entrepreneurship and Small Business, 13(1), 75-91.

Kashdan, T. B., Rose, P., \& Fincham, F. D. (2004). Curiosity and exploration: Facilitating positive subjective experiences and personal growth opportunities. Journal of Personality Assessment, 82(3), 291-305.

Kaufman, J. C. (2006). Self reported differences in creativity by ethnicity and gender. Applied Cognitive Psychology, 20(8), 1065-1082.

Kaufman, J. C., \& Baer, J. (2004). Sure, I'm Creatve-But not in Mathematics!: Self-reported Creativity in Diverse Domains. Empirical Studies of the Arts, 22(2), 143-155.

Kaufman, J. C., Cole, J. C., \& Baer, J. (2009). The Construct of Creativity: Structural Model for Self Reported Creativity Ratings. The Journal of Creative Behavior, 43(2), 119134.

Kidd, J. M. (1984). Young people's perceptions of their occupational decision-making. British Journal of Guidance and Counselling, 12(1), 25-38.

Klofsten, M. (2000). Training entrepreneurship at universities: a Swedish case. Journal of European Industrial Training, 24(6), 337. Retrieved from http://search.ebscohost.com/login.aspx?direct=true $\& d b=b t h \& A N=3646502 \&$ site=ehostlive

Knight, F. H. (2012). Risk, uncertainty and profit. Courier Dover Publications.

Kolvereid, L., \& Moen, Ø. (1997). Entrepreneurship among business graduates: does a major in entrepreneurship make a difference? Journal of European Industrial Training, 21(4), $154-160$. 
Korsgaard, S. (2011). Entrepreneurship as translation: Understanding entrepreneurial opportunities through actor-network theory. Entrepreneurship \& Regional Development, 23(7-8), 661-680.

Krumboltz, J. D. (1979). A social learning theory of career decision making. In A. M. Mitchell, G. B. Jones, \& J. D. Krumboltz (Eds.), Social Learning and Career Decision Making. Cranston, RI: Carroll Press.

Lasch, F. (2011). Beyond the concept of human and social capital: the impact of the regional environment on high-tech venturing. International Journal of Entrepreneurship and Small Business, 14(1), 56-76.

Law, B. (1981). Community interaction: a "mid-range"focus for theories of career development in young adults. British Journal of Guidance and Counselling, 9(2), 142158.

Le, A. T. (1999). Empirical studies of self employment. Journal of Economic Surveys, 13(4), $381-416$.

Leiblein, M. J. (2007). Environment, organization, and innovation: how entrepreneurial decisions affect innovative success. Strategic Entrepreneurship Journal, l(1 2), 141144.

Leonard, N. H., \& Harvey, M. (2007). The Trait of Curiosity as a Predictor of Emotional Intelligence1. Journal of Applied Social Psychology, 37(8), 1914-1929.

Lounsbury, J. W., \& Gibson, L. W. (2002). Personal Style Inventory: A work-based personality measurement system. Resource Associates, Knoxville, TN.

Lounsbury, J. W., Hutchens, T., \& Loveland, J. M. (2005). An investigation of big five personality traits and career decidedness among early and middle adolescents. Journal of Career Assessment, 13(1), 25-39.

Lounsbury, J. W., Tatum, H. E., Chambers, W., Owens, K. S., \& Gibson, L. W. (1999). An investigation of career decidedness in relation to" Big Five" personality constructs and life satisfaction. College Student Journal.

Lüthje, C., \& Franke, N. (2002). Fostering entrepreneurship through university education and training: Lessons from Massachusetts Institute of Technology. In European Academy of Management 2nd Annual Conference on Innovative Research in Management, Stockholm (pp. 9-11).

Luzzo, D. A. (1993). Value of career-decision-making self-efficacy in predicting careerdecision-making attitudes and skills. Journal of Counseling Psychology, 40(2), 194.

Marcia, J. E. (1980). Identity in adolescence. Handbook of Adolescent Psychology, 9, 159187.

Maritz, A. (2004). New Zealand necessity entrepreneurs. International Journal of Entrepreneurship and Small Business, 1(3), 255-264.

Meertens, R. M., \& Lion, R. (2008). Measuring an Individual's Tendency to Take Risks: The Risk Propensity Scale1. Journal of Applied Social Psychology, 38(6), 1506-1520.

Mohamad, N., Lim, H.-E., Yusof, N., Kassim, M., \& Abdullah, H. (2014). Estimating the Choice of Entrepreneurship as a Career: The Case of Universiti Utara Malaysia. International Journal of Business \& Society, 15(1), 65-80. Retrieved from $\mathrm{http} / / /$ search.ebscohost.com/login.aspx?direct=true \&db=bth\&AN=95257580\&site=ehos t-live

Nasr, S., \& Rostom, A. M. (2013). SME contributions to employment, job creation, and growth in the Arab world. Job Creation, and Growth in the Arab World (October 1, 2013).

Neff, K. D., Rude, S. S., \& Kirkpatrick, K. L. (2007). An examination of self-compassion in relation to positive psychological functioning and personality traits. Journal of Research in Personality, 41(4), 908-916.

Nijkamp, P. (2003). Entrepreneurship in a modern network economy. Regional Studies, $37(4), 395-405$.

O'higgins, N. (1997). The challenge of youth unemployment. International Social Security Review, 50(4), 63-93. 
Olson, P. D. (1987). Entrepreneurship and management. Journal of Small Business Management, 25, 7 .

Owualah, S. L. (1999). Tackling youth unemployment through entrepreneurship. International Small Business Journal, 17(3), 49-59.

Peredo, A. M., Anderson, R. B., Galbraith, C. S., \& Honig, B. (2004). Towards a theory of indigenous entrepreneurship. International Journal of Entrepreneurship and Small Business, 1(1), 1-20.

Peterman, N. E., \& Kennedy, J. (2003). Enterprise education: Influencing students' perceptions of entrepreneurship. Entrepreneurship Theory and Practice, 28(2), 129144.

Piore, M. J., \& Sabel, C. F. (1984). The Second Industrial Divide: Possibilities for Prosperity. Basic Books. Retrieved from http://books.google.it/books?id=D7TseoWoSbMC

Porfeli, E. J., \& Skorikov, V. B. (2010). Specific and diversive career exploration during late adolescence. Journal of Career Assessment, 18(1), 46-58.

Poschke, M. (2013). Who becomes an entrepreneur? Labor market prospects and occupational choice. Journal of Economic Dynamics and Control, 37(3), 693-710.

Ramadani, V., Gërguri, S., Dana, L.-P., \& Tašaminova, T. (2013). Women entrepreneurs in the Republic of Macedonia: waiting for directions. International Journal of Entrepreneurship and Small Business, 19(1), 95-121.

Rees, H., \& Shah, A. (1986). An empirical analysis of self employment in the UK. Journal of Applied Econometrics, 1(1), 95-108.

Reynolds, P. D. (1991). Sociology and Entrepreneurship: Concepts and Contributions. Entrepreneurship Theory and Practice, 16(2), 47-70.

Reynolds, P., Storey, D. J., \& Westhead, P. (1994). Cross-national comparisons of the variation in new firm formation rates. Regional Studies, 28(4), 443-456.

Ritsilä, J., \& Tervo, H. (2002). Effects of unemployment on new firm formation: Micro-level panel data evidence from Finland. Small Business Economics, 19(1), 31-40.

Rodrigues, R. G., Raposo, M., Ferreira, J., \& Do Paco, A. (2010). Entrepreneurship education and the propensity for business creation: testing a structural model. International Journal of Entrepreneurship and Small Business, 9(1), 58-73.

Rohrmann, B. (2002). Risk attitude scales: Concepts and questionnaires. Melbourne: University of Melbourne, 12.

Rohrmann, B. (2005). Risk attitude scales: concepts, questionnaires, utilizations. Project Report. Online Access Http://www. Rohrmannresearch. Net/pdfs/rohrmann-Ras-Report. Pdf, 13, 2012.

Ronay, R., \& Kim, D. (2006). Gender differences in explicit and implicit risk attitudes: A socially facilitated phenomenon. British Journal of Social Psychology, 45(2), 397-419.

Roszkowski, M. J., \& Grable, J. E. (2009). Evidence of lower risk tolerance among public sector employees in their personal financial matters. Journal of Occupational and Organizational Psychology, 82(2), 453-463.

Russell, M. T., \& Karol, D. L. (1994). The 16PF fifth edition administrator's manual. Institute for Personality and Ability Testing Champaign, IL.

Saddi, J., \& Soueid, R. (2011). Accelerating Entrepreneurship in the Arab World (Vol. October 20). World Economic Forum.

Scarpetta, S., Sonnet, A., \& Manfredi, T. (2010). Rising youth unemployment during the crisis. Documents de Travail de l'OCDE Sur Les Affaires Sociales, L'emploi et Les Migrations, 106.

Schumpeter, J. (1934). The Theory of Economic Development: an Inquiry into Profits, Capital, Credit, Interest, and the Business Cycle. Cambridge, MA: Harvard University Press.

Shane, S., \& Cable, D. (2002). Network ties, reputation, and the financing of new ventures. Management Science, 48(3), 364-381.

Silvia, P. J., Wigert, B., Reiter-Palmon, R., \& Kaufman, J. C. (2012). Assessing creativity with self-report scales: A review and empirical evaluation. Psychology of Aesthetics, Creativity, and the Arts, 6(1), 19. 
Silvia, P. J., Winterstein, B. P., Willse, J. T., Barona, C. M., Cram, J. T., Hess, K. I., ... Richard, C. A. (2008). Assessing creativity with divergent thinking tasks: Exploring the reliability and validity of new subjective scoring methods. Psychology of Aesthetics, Creativity, and the Arts, 2(2), 68.

Singh, R. P. (2001). A comment on developing the field of entrepreneurship through the study of opportunity recognition and exploitation. Academy of Management Review, 26(1), $10-12$.

Smart, J. C. (1986). College effects on occupational status attainment. Research in Higher Education, 24(1), 73-95.

Spicer, D. P., \& Sadler-Smith, E. (2005). An examination of the general decision making style questionnaire in two UK samples. Journal of Managerial Psychology, 20(1/2), 137-149.

Retrieved

from

http://proxygw.wrlc.org/login?url=http://search.proquest.com/docview/215868675?acco untid $=11243$

Super, D. E. (1953). A theory of vocational development. American Psychologist, 8(5), 185.

Tackey, N. D. (1999). Graduate business start-ups. IES, Brighton.

The World Bank. (2015). Jordan Overview. Retrieved March 27, 2015, from http://www.worldbank.org/en/country/jordan/overview

Thurik, R., \& Wennekers, S. (2004). Entrepreneurship, small business and economic growth. Journal of Small Business and Enterprise Development, 11(1), 140-149.

Todorovic, Z. W., \& McNaughton, R. B. (2007). The effect of culture, resources and quality of entrepreneurship on economic development: a conceptual framework. International Journal of Entrepreneurship and Small Business, 4(4), 383-396.

U.S. Department of Commerce. (2014). Doing Business in Jordan: 2014 Country Commercial Guide for U.S. Companies. Retrieved from http://photos.state.gov/libraries/jordan/444376/pdf/2014CCGFinal.pdf

Uthayakumar, R., Schimmack, U., Hartung, P. J., \& Rogers, J. R. (2010). Career decidedness as a predictor of subjective well-being. Journal of Vocational Behavior, 77(2), 196-204.

Van Auken, H., Fry, F. L., \& Stephens, P. (2006). The influence of role models on entrepreneurial intentions. Journal of Developmental Entrepreneurship, 11(02), 157167.

Vesper, K. H., \& Gartner, W. B. (1997). Measuring progress in entrepreneurship education. Journal of Business Venturing, 12(5), 403-421.

Vogel, P. (2013). The Employment Outlook for Youth: Building Entrepreneurship Ecosystems as a Way Forward. In Conference Proceedings of the G20 Youth Forum.

Winefield, A. H. (1997). Editorial: Introduction to the psychological effects of youth unemployment: international perspectives. Journal of Adolescence, 20(3), 237-241.

Zellweger, T., Sieger, P., \& Halter, F. (2011). Should I stay or should I go? Career choice intentions of students with family business background. Journal of Business Venturing, 26(5), 521-536.

Zimmerman, M. A., \& Zeitz, J. G. (2002). Beyond Survival: Achieving New Venture Growth by Building Legitimacy. Academy of Management Review, 27(3), 414-431. 